\title{
A NATURAL REGIONS MAP FOR TASMANIA
}

\author{
by A. E. Orchard
}

(with two text-figures)

ORCHARD, A. E., 1988 (31:x): A natural regions map for Tasmania. Pap. Proc. R. Soc. Tasm. 122(2): 47-51 https://doi.org/10.26749/rstpp.122.2.47 ISSN 0080-4703.

Tasmanian Herbarium, G.P.O. Box 252C, Hobart, Australia 7001.

Tasmania has been divided into 13 regions for the purpose of mapping plant distribution. Eleven of these regions are large ecogeographic zones, the other two being defined to accommodate historic and administrative requirements of the Tasmanian Herbarium. The boundaries of all regions are defined on natural features, principally rivers and altitudinal contours. The region names are being routinely added to labels of specimens in the $T$ asmanian Herbarium. Very similar regions are recognised in a scheme being used by other agencies in Tasmania for nature conservation purposes, and the differences between the two schemes are discussed.

Key Words: ecogeographic regions, Tasmania, Tasmanian Herbarium.

\section{INTRODUCTION}

Botanical regions, based on a range of criteria, have been defined for most Australian states (see Barlow 1984 for a summary). Most schemes have been developed by state herbaria, where they are found to be particularly useful for internal collection management purposes. Many authors also use these schemes as convenient and more or less natural frameworks within which to describe plant distribution, particularly in taxonomic revisions and considerations of plant conservation.

Tasmania has never had a scheme of welldefined botanical regions for a number of reasons. Firstly, the Tasmanian Herbarium was only formally established in $1977 / 78$. Secondly, Tasmania is the smallest state, and in terms of area would fit many times over into some of the botanical regions used in other states. Finally, through a combination of climate, topography, evolutionary history and other factors, Tasmania has perhaps the most intricate mosaic of vegetation types in Australia. As an illustration of this latter point, it is possible, for example, to set up a transect from Pitt Water near Hobart Airport to the top of Mt Wellington, a linear distance of $25 \mathrm{~km}$, which takes in coastal sanddune communities, salt marshes, dry sclerophyll forest and savannah, riverine wetlands, wet sclerophyll forest, cool temperate rainforest, subalpine heathland and subalpine cushion plant communities. In fact the only major Tasmanian plant communities missing in this transect are the buttongrass swamp and other vegetation types developed on the quartzite/peat soils of the southwest and west coast.
Undefined vernacular descriptors (east coast, midlands, Western Tiers, central plateau, southwest) have been used informally to describe more or less natural regions in Tasmania for many years. Davies (1964) produced a map of the six main contemporary vegetation types in Tasmania (see also Jackson 1965), and Kirkpatrick \& Dickinson (1984) provided a much more detailed map which recognised 49 different communities. Mosley (1974) produced a map of 12 "floristic zones", which subsequently formed the basis for some assessments of the distribution and conservation status of individual species and communities, e.g. Brown et al . 1977, Leigh et al. 1981. The boundaries of these zones were not defined, and some zones encompassed a very wide range of vegetation types. Barlow $(1984,1986)$ adopted a much simpler approach, by treating the whole of Tasmania as a single botanical region. The Bureau of Flora and Fauna with their Census of Australian Plants (unpublished) attempted to relate species distribution in Tasmania to three regions, but again these had undefined boundaries.

In 1980, in the absence of any existing, widely accepted system of botanical regions in Tasmania it was decided to devise one, initially for use only as a management tool within the Tasmanian Herbarium. In drawing up the map, the following criteria were taken into account:

(i) the number of regions was not to exceed 15 , and should if possible be fewer;

(ii) the regions were to be biogeographically based, taking into account the climatic regions of Gentilli (1972), the vegetation map of Davies (1964) and the floristic zones of Mosley (1974); (iii) the boundaries had to be unambiguous, based 

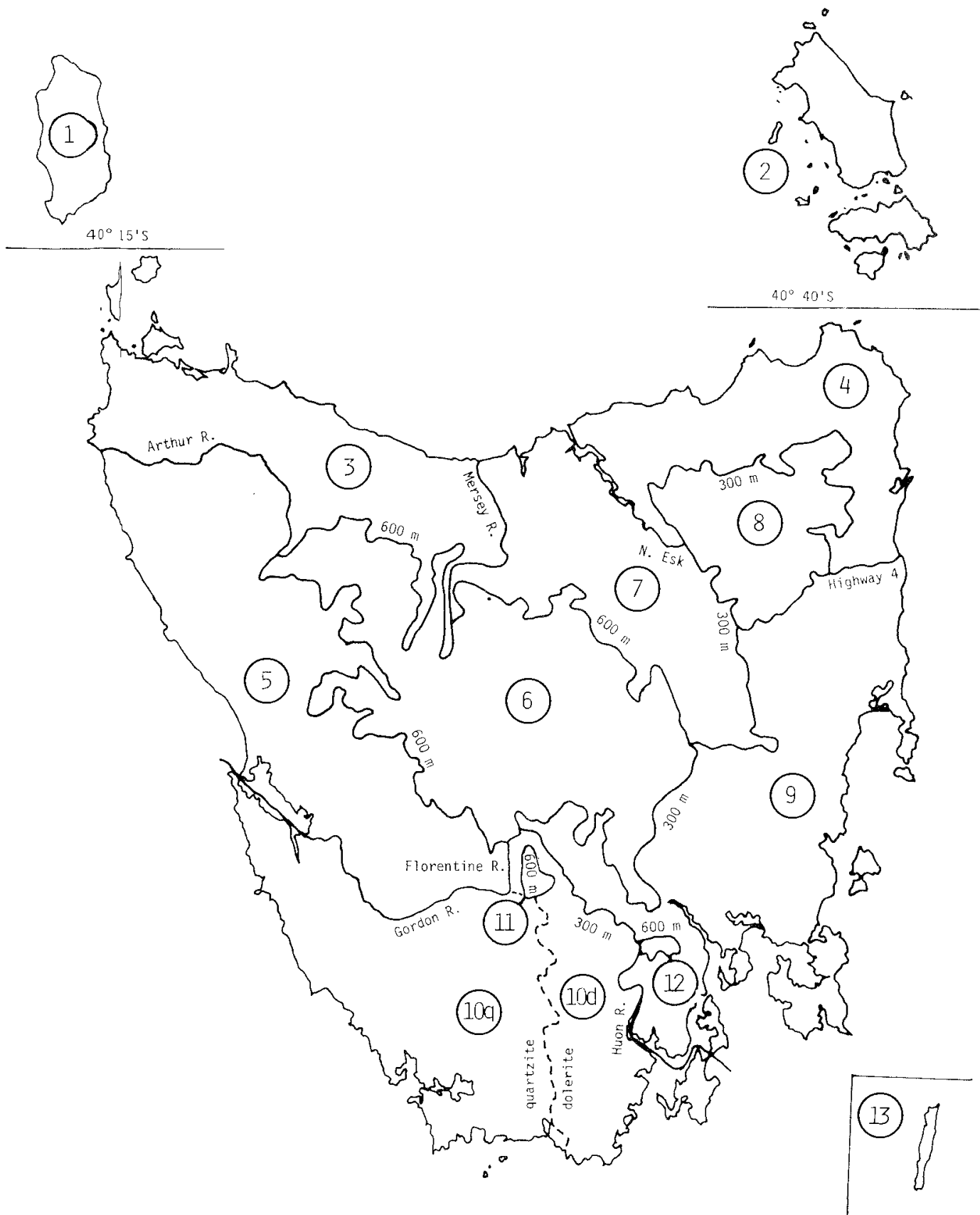

FIG. I-Regions used by the Tasmanian Herbarium: (1) King Island, (2) Furneaux, (3) North West, (4) North East, (5) West Coast, (6) Central Highlands, (7) Midlands, (8) Ben Lomond, (9) East Coast. (10q) South West (quartzite), (10d) South West (dolerite), (11) Mt Field. (12) Mt Wellington. (13) Macquarie Island. 
as far as possible on natural features, and definable in two-three sentences; and

(iv) the names of the regions were to retain, as far as possible, vernacular usage.

\section{THE REGIONS}

A set of 13 regions was recognised (fig. 1), and defined.

(1) King Island. Includes King Island itself, plus associated islets and reefs north of latitude $40^{\circ} 15^{\prime} \mathrm{S}$.

(2) Furneaux. Includes the main Furneaux Group (Flinders, Cape Barren and Clarke Islands and associated islets north of latitude $40^{\circ} 40^{\prime} \mathrm{S}$ ) as well as the Kent, Curtis and Hogan Groups up to the Victorian border (latitude $39^{\circ} 12^{\prime} \mathrm{S}$ ).

(3) North West. The southwestern boundary is formed by the Arthur River upstream to near Waratah. It then turns eastward along $600 \mathrm{~m}$ altitudinal contour. The eastern boundary is the Mersey River. Three Hummock, Hunter and Robbins Islands fall within this region.

(4) North East. The western boundary is the Tamar estuary. The southern boundary follows the North Esk River to the $300 \mathrm{~m}$ altitudinal contour, then along this line north of the Ben Lomond massif to Highway 4 between Fingal and Scamander.

(5) West Coust. Abuts region 3 in the north. The eastern boundary is the $600 \mathrm{~m}$ contour line while the southern boundary is Macquarie Harbour and the Gordon River. The southeastern extremity is bounded by the Florentine River.

(6) Central Highlands. The northern, western and northeastern boundaries are the $600 \mathrm{~m}$ contour line. In the east this contour line is joined to the $300 \mathrm{~m}$ line by the Blackman River, and the $300 \mathrm{~m}$ line is followed to the Florentine and Gordon Rivers.

(7) Midlands. The western boundary is the Mersey River, the eastern boundary is the Tamar Estuary, the North Esk River and then via the $300 \mathrm{~m}$ contour along the southeastern and southern boundaries to the Blackman River. On the southwestern side this region abuts the central highlands.

(8) Ben Lomond. The Mt Arthur, Mt Barrow, Ben Lomond and Mt Saddleback complex, down to the $300 \mathrm{~m}$ contour line.

(9) East Coast. In the north the boundary is Highway 4 betwecn Fingal and Scamander, until the point where it meets the $300 \mathrm{~m}$ contour. This line forms the western boundary until it meets the Huon River near Judbury. This region includes the upper Derwent Valley and north Bruny Island. (10) South West. Abuts regions 5, 6 and 9 and includes south Bruny Island. Contains region 11 as an enclave. It can be divided into two subregions (q) and (d) defined by the underlying rock type $(q=$ quartzite, $d=$ dolerite $)$.

(11) Mt Field. Consists of Mt Field East and Mt Field West, down to the $600 \mathrm{~m}$ contour line.

(12) Mt Wellington. The Mt Wellington range down to the $600 \mathrm{~m}$ contour line.

(13) Macquarie lsland.

\section{DISCUSSION}

Some comments are necessary on the above scheme. Two regions, Mt Field and Mt Wellington, are arbitrary. Both have been singled out for special recognition within the Tasmanian Herbarium because they are the two most heavily collected and botanically visited areas in the state. However, on other criteria Mt Wellington clearly belongs in the South West region, while Mt Field would be allocated to region 6 or $10(d)$. Some other boundaries are somewhat arbitrary (for example those between regions $3 \& 5$, and $3 \& 7$ ) and have the consequence of stretching vernacular understanding of some districts (e.g. Deloraine and Mole Creek fall within "Midlands", the upper Derwent valley within "East Coast" and South Bruny Island within "South West"). However these quirks must be tolerated if a manageable number of regions with easily defined boundaries is to be achieved.

These regions have been in use in the Tasmanian Herbarium now for over six years, and have been routinely added to all specimen labels produced in that time. No serious difficulties have been experienced in quickly allocating collections to their correct region. The region names will be used in future editions of The Student's Flora of Tasmania and in at least some taxonomic monographs to describe plant distributions within the state.

In 1984 the Tasmanian Forestry Commission convened a meeting to discuss the preparation of definitions of biophysical/biogeographic regions within Tasmania, to be used in the first instance in an Environmental Impact Study on Woodchip Exports (Anon. 1985). The Commission decided to adopt the Herbarium scheme with minor modifications, and produced a map (fig. 2) showing eleven Nature Conservation Regions, each rigidly defined on criteria similar or identical to those of the Herbarium scheme. 

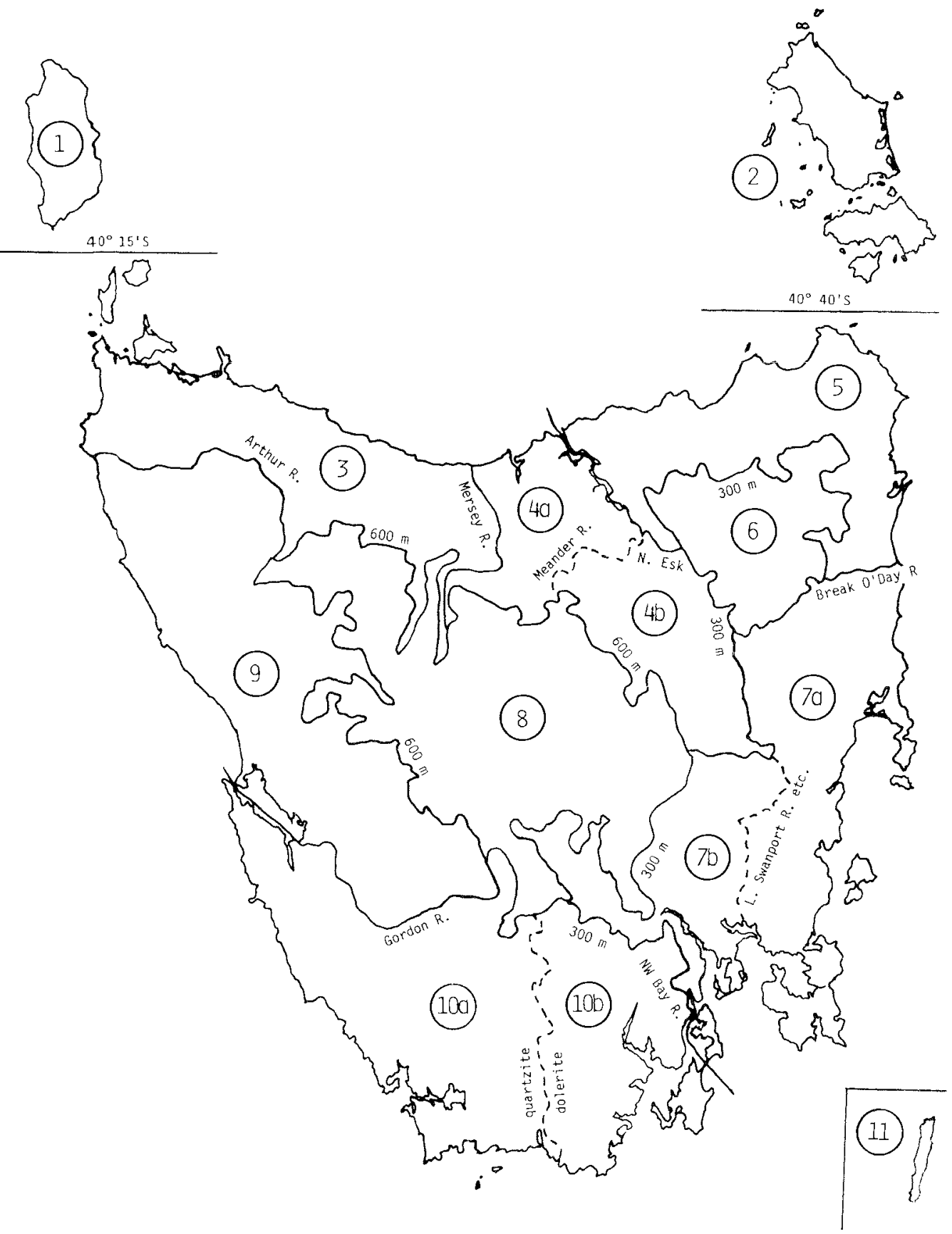

FIG. 2 - Nature Conservation Regions adopted by the Tasmanian Forestry Commission: (I) King Island, (2) Furneaux Group, (3) North west, (4) North (4a-Coast and Hills, 4 b-Midlands). (5) North East Lowlands, (6) North East Highlands, (7) East (7a-Coast and Tiers, 7b-Southern Midlands), (8) Centre, (9) West, (10) South (10a-quartzite, IOb-dolerite), (II) Macquarie Island. 
The major differences between the two maps (referred to here for convenience as the Herbarium and Forestry schemes) are:

(i) the "Midlands" region of the Herbarium map ("North" on the Forestry map) is divided by Forestry at the Meander River and Quamby Brook into two subregions called "Coast and Hills" and "Midlands";

(ii) the "East Coast" region of the Herbarium map is divided by Forestry along the Tasman Highway, Woodsdale Road, Stonehenge Road, Little Swanport River, Green Tier Creek and Tooms Lake Road into two subregions called "Coast and Tiers" and "Southern Midlands";

(iii) the Herbarium's "Mt Field" region is included within the Forestry "Centre" (= "Central Highlands") region;

(iv) the Herbarium's "Mt Wellington" region is included within the Forestry "South" region; and

(v) in the Forestry scheme the eastern boundary of the "South" (="South West") region is moved eastwards from the Huon River to North West Bay River.

As well as the Forestry Commission, other organisations such as the Tasmanian National Parks and Wildlife Service have adopted the modified scheme for some conservation studies (e.g. Duncan 1986). For most purposes, the two schemes can be considered essentially identical. In critical cases if the source of the particular scheme is being followed is not clearly identified, it should be possible to ascertain this by the nomenclature adopted, which differs for most regions in the Herbarium and Forestry maps.

\section{REFERENCES}

ANONYMOUS, 1985: ENVIRONMENTAL IMPACT STUDY ON TASMANIAN WOODCHIP EXPORTS BEYOND 1988. Tasmanian Woodchip Study Group, Hobart.

BARLOW, B.A., 1984: Proposal for delineation of botanical regions in Australia. Brunonia 7: 195-201

BARLOW, B.A., 1986: A revised natural regions map for Australia. Brunonia 8: 387-92.

BROWN, M.J., HOGGINS, D.D. \& BAYLY-STARK, H.J., 1977: Conservation of flora in Tasmaniat. Tech. Rep. 77/4. Tasm. Nat. Pks Wildl. Serv.

DAVIES, J.L., 1964: A vegetation map of Tasmania. Geog. Rev. 54: 249-253.

DUNCAN, F., 1986: Vegetation survey of non-allocated Crown land in Tasmania. Report No. 1. Tech. Rep. 86/2. Tasm. Nat. Pks Wildl. Serv.

GENTILLI, J., 1972: AUSTRALIAN CLIMATE PATTERNS. Nelson, Melbourne.

JACKSON, W.D., 1965: Vegetation. In Davies, J. L. (Ed.): ATLAS OF TASMANIA. Lands and Survey Department, Hobart.

KIRKPATRICK, J.B. \& DICKINSON, K.J.M., 1984: VEGETATION OF TASMANIA (Map). Forestry Commission, Tasmania.

LEIGH, J., BRIGGS, J. \& HARTLEY, W., 1981: Rare or threatened Australian plants. Aust. Natl Pks Wildl. Serv. Spec. Pub. No. 7

MOSLEY, J.G., 1974: Conservation in Tasmania. In Specht, R. L., Roe, E.M. \& Boughton, V. H. (Eds.): CONSERVATION OF MAJOR PLANT COMMUNITIES IN AUSTRALIA AND PAPUA NEW GUINEA. Aust. J. Bot. Suppl. 7: 320.

(accepted 11March 1988) 